\begin{tabular}{|c|c|c|}
\hline \multirow{3}{*}{$\begin{array}{r}\text { Case Reports in } \\
\text { Gastroenterology }\end{array}$} & \multirow{2}{*}{\multicolumn{2}{|c|}{ Case Rep Gastroenterol 2014;8:123-128 }} \\
\hline & & \\
\hline & $\begin{array}{l}\text { DOI: 10.1159/000362441 } \\
\text { Publisned online: Aprill 5, } 2014\end{array}$ & $\begin{array}{l}\text { (c) } 2014 \text { S. Karger AG, Basel } \\
\text { 1662-0631/14/0081-0123\$39.50/0 } \\
\text { www.karger.com/crg }\end{array}$ \\
\hline & \multicolumn{2}{|c|}{$\begin{array}{l}\text { This is an Open Access article licensed under the terms of the Creative Commons } \\
\text { Attribution-NonCommercial } 3.0 \text { Unported license (CC BY-NC) (www.karger.com/OA } \\
\text { license), applicable to the online version of the article only. Distribution permitted for non } \\
\text { commercial purposes only. }\end{array}$} \\
\hline
\end{tabular}

\title{
Functional Aerophagia in Children: A Frequent, Atypical Disorder
}

\author{
Giuliana Morabito Claudia Romeo Claudio Romano \\ Pediatric Department, University of Messina, Messina, Italy
}

\section{Key Words}

Bloating · Aerophagia · Megacolon · Functional gastrointestinal disorders · Pediatric

\begin{abstract}
Aerophagia is a functional gastrointestinal disorder characterized by repetitive air swallowing, abdominal distension, belching and flatulence. Pathologic aerophagia is a condition caused by the swallowing of excessive volumes of air with associated various gastrointestinal symptoms, such as burping, abdominal cramps, flatulence and a reduced appetite. It is a clinical entity that can simulate pediatric gastrointestinal motility disorders, such as gastroparesis, megacolon and intestinal pseudo-obstruction, and presents more frequently in children with mental retardation. Early recognition and diagnosis of functional aerophagia or pathologic aerophagia is required to avoid unnecessary, expensive diagnostic investigations or serious clinical complications. Functional aerophagia is frequent in the adult population, but rarely discussed in the pediatric literature. We present two pediatric clinical cases with a history of functional constipation in whom gaseous abdominal distension was the most important symptom. Mechanical intestinal obstruction, chronic intestinal pseudo-obstruction, malabsorption and congenital aganglionic megacolon were ruled out. Extensive gaseous abdominal distension was due to aerophagia, and treatment consisted of parents' reassurance and psychological counseling.

(c) 2014 S. Karger AG, Basel
\end{abstract}

\section{Introduction}

Functional aerophagia (FA) involves excessive air swallowing causing progressive abdominal distension. The typical clinical presentation is a non-distended abdomen in the morning, progressive abdominal distension during the day, visible, often audible, air swallowing and excessive flatus. When FA is associated with various gastrointestinal symptoms, such as burping, abdominal pain, flatulence and belching, this condition is de-

Claudio Romano

Pediatric Department, University of Messina

Via Consolare Valeria, IT-98125 Messina (Italy)

E-Mail romanoc@unime.it 
Morabito et al.: Functional Aerophagia in Children: A Frequent, Atypical Disorder

fined as pathologic aerophagia [1]. Pathologic aerophagia is present in $8.8 \%$ of the mentally retarded population [2]. The mechanisms of onset of FA are correlated with involuntary paroxysmal openings of the cricopharyngeal sphincter followed by air swallows without cricopharyngeal swallowing movement sequences [3]. The Rome II and III criteria for functional gastrointestinal disorders (FGIDs) include the definition of aerophagia [4]. In many reported cases, the diagnosis is missed initially and parents often deny a functional origin of the disease to search for organic diseases. Gastrointestinal symptoms can be associated with a reduction in oral intake. We describe two pediatric cases of FA without underlying mental retardation.

\section{Case 1}

An 8-year-old boy was admitted with a history of abdominal bloating associated with rectal tenesmus and increased flatus. These symptoms recurred especially during the afternoon and evening. No associated gastrointestinal symptoms were reported. His clinical history was characterized by rumination in the first years of life with associated non-organic feeding disorders as a picky eater. Radioallergosorbent test for alimentary and inhalant allergens, skin prick tests and celiac screening was negative. Ultrasonography did not reveal any organomegaly or fluid presence in the abdomen. Abdominal radiographs showed a distended colon with increased gas in the rectum and coprostasis, without signs of obstruction. On physical examination, weight was $22 \mathrm{~kg}$ and height $129 \mathrm{~cm}$, with a mild degree of malnutrition according to the Waterloo classification. Cardiorespiratory objectivity was normal. A significantly non-tender, hypertympanitic abdominal distension was present. No hepatomegaly nor splenomegaly were noted. Rectal examination revealed a sensation of hypertonic anus sphincter without perineal erythema and stool. Neurologic examination was normal. The following laboratory investigations were performed: complete blood count (red blood cell count $5.1 \times 10^{6} / \mathrm{mm}^{3}$, Hb $13.8 \mathrm{~g} / \mathrm{dl}$, HCT 43\%, MCV $84 \mathrm{fl}$, white blood cell count $5 \times 10^{3} / \mathrm{mm}^{3}$, neutrophils $34 \%$, lymphocytes $60 \%$, monocytes $4 \%$, eosinophils $2 \%$, basophils $0 \%$, platelets $297 \times 10^{3} / \mathrm{mm}^{3}$ ), C-reactive protein was $0.10 \mathrm{mg} / \mathrm{dl}$ (normal $0-0.50 \mathrm{mg} / \mathrm{dl}$ ), erythrocyte sedimentation rate $5 \mathrm{~mm}$ within the first hour, glycemia $68 \mathrm{mg} /$ $\mathrm{dl}$, serum glutamic oxaloacetic transaminase $26 \mathrm{IU} / \mathrm{l}$, serum glutamic pyruvate transaminase $14 \mathrm{IU} / \mathrm{l}$, serum gamma-GT $7 \mathrm{IU} / \mathrm{l}$, amylase $67 \mathrm{U} / \mathrm{l}$, lipase $27 \mathrm{U} / \mathrm{l}$, BUN $26 \mathrm{mg} / \mathrm{dl}$, creatine $0.5 \mathrm{mg} / \mathrm{dl}$, iron $54 \mu \mathrm{g} / \mathrm{dl}$, sodium $140 \mathrm{mmol} / \mathrm{l}$, potassium $4.3 \mathrm{mmol} / \mathrm{l}$, calcium $9.78 \mathrm{mg} / \mathrm{dl}$, total proteins $7.1 \mathrm{~g} / \mathrm{dl}$, and albumin $48 \mathrm{~g} / \mathrm{l}$; coagulation parameters and urinalysis were normal. Also, lactate dehydrogenase (395 U/l), muscle enzymes (creatine phosphate kinase $75 \mathrm{IU} / \mathrm{l}$, CK-MB $10 \mathrm{IU} / \mathrm{l}$ ), thyroid hormones (free thyroxine $10.98 \mathrm{pmol} / \mathrm{l}$, thyroid-stimulating hormone $1.925 \mu \mathrm{IU} / \mathrm{ml}$ ), celiac serology, cytomegalovirus, Epstein-Barr virus, herpesvirus serology and autoantibodies (ANA, nDNA, ANCA) were normal, and megacolon was excluded using barium enema. After ruling out primary pathologic causes, a neuropsychiatric consultation was requested with the disclosure of continuous aerophagia and anxiety disorder with obsessive compulsive notes and game-playing dependency. It was possible to reassure the family on the absence of an organic gastrointestinal disease with indications to neuropsychiatric and cognitive follow-up. 
Morabito et al.: Functional Aerophagia in Children: A Frequent, Atypical Disorder

\section{Case 2}

A 7-year-old girl, affected by autistic spectrum disorder, was admitted to our hospital for abdominal distension and constipation that had started at 2 years of age. A history of severe abdominal distension and bloating was present chronically, especially in the postprandial period until the evening. The chronic constipation was treated with macrogol. The patient's general condition at admission was good, weight was $23 \mathrm{~kg}$ and height $121 \mathrm{~cm}$. Physical examination showed excessive air swallowing associated with visible abdominal distension, in the absence of organomegaly, and significant bloating. No abdominal pain or other gastrointestinal symptoms were present. A routine basic metabolic panel was performed with red blood cell count $4.3 \times 10^{6} / \mathrm{mm}^{3}$, Hb $11.8 \mathrm{~g} / \mathrm{dl}$, white blood cell count $6.5 \times$ $10^{3} / \mathrm{mm}^{3}$ (neutrophils $44 \%$, lymphocytes $51 \%$, monocytes $3 \%$, eosinophils $2 \%$, basophils $0 \%$ ), platelets $278 \times 10^{3} / \mathrm{mm}^{3}$, C-reactive protein $0.10 \mathrm{mg} / \mathrm{dl}$, erythrocyte sedimentation rate $7 \mathrm{~mm}$ within the first hour, lactate dehydrogenase $518 \mathrm{U} / \mathrm{l}$, glycemia $79 \mathrm{mg} / \mathrm{dl}$, serum glutamic oxaloacetic transaminase $34 \mathrm{IU} / \mathrm{l}$, serum glutamic pyruvate transaminase $19 \mathrm{IU} / \mathrm{l}$, serum gamma-GT $8 \mathrm{IU} / \mathrm{l}$, total proteins $6.6 \mathrm{~g} / \mathrm{dl}$ and serum iron $56 \mu \mathrm{g} / \mathrm{dl}$; serum electrolytes, celiac serology, coproculture and a parasitologic examination of stools were negative. Abdominal ultrasound showed increased gas in the small and large bowel without signs of obstruction. Abdominal radiography confirmed distension of the large and small bowel and presence of coprostasis. Anorectal manometry showed a normal recto-anal reflex of $30 \mathrm{ml}$. Neuropsychiatric consultation pointed out a moderate retardation of psychomotor stages and considered aerophagia as a stereotype symptom. A diagnosis of FA was made with indication of a cognitive-behavioral approach and associated therapy with macrogol, simethicone and otilonium bromide.

\section{Discussion}

Aerophagia involves excessive air swallowing causing progressive abdominal distension. The symptoms in children are a non-distended abdomen in the morning, progressive abdominal distension during the day, visible, often audible, air swallowing and excessive flatus. Resolution of the abdominal distension occurs during the night by absorption of gas and by flatulence [5]. Aerophagia can occur in sudden acute attacks but also chronically. It has been included in the FGID Classification from the Rome II criteria for irritable bowel syndrome and the Rome III Committee Consensus (table 1). Management of the disorder implies a correct diagnosis with a careful history and a minimal number of diagnostic studies to exclude organic disease (malabsorption and intestinal obstruction) [2]. An overlapping of FA with other FGID-like irritable bowel syndrome or constipation can be found. There are no studies about the prevalence of this condition in a pediatric population without mental retardation and the correct diagnosis is missed in most patients. Typical clinical symptoms include progressive abdominal distension and flatus that can be present during the night as a result of increased parasympathomimetic activity during sleeping that causes gastrointestinal motility disorder. Involuntary cricopharyngeal sphincter openings may be presumed to disappear during sleep, resulting in a non-distended abdomen in the morning.

Pathologic childhood aerophagia is defined as a condition of chronic aerophagia associated with gastrointestinal symptoms such as abdominal and epigastric pain, reduced appetite and burping [3]. FA in healthy patients implies a diagnosis on the basis of the presence of diagnostic clinical criteria combined with a normal physical examination. A careful history and a minimal number of diagnostic studies can exclude organic disease, 
Morabito et al.: Functional Aerophagia in Children: A Frequent, Atypical Disorder

such as malabsorption or intestinal obstruction. Supplementary investigations should be performed based on case history and physical examination [4] (table 2). The correct diagnosis helps in alleviating anxiety and prevents unnecessary testing, treatments and hospital admission [2]. The most satisfactory diagnostic criteria is abdominal distension that progressively increases during the course of the day (minimum in the early morning and maximum in the late evening, fig. 1), increased flatus during sleep, increased bowel sounds on auscultation of distended abdomen and an abdominal radiograph done in the late afternoon showing an air-distended stomach and increased gas in the small and large bowel without signs of obstruction (fig. 2). In healthy children with high sensitivity and introverted personalities, who present aerophagia as part of a functional disease, the symptoms are precipitated by psychological stress. In a large retrospective analysis of these patients, a high prevalence of anxiety and depression has been found [6]. These findings strongly suggest that aerophagia is a behavioral disorder.

In clinical management, a distinction between primary and secondary aerophagia can help identify different risk profiles for surgical complications or emergency situations. A distinction should be made between patients with aerophagia who have chronic stable symptoms and patients with acute and severe episodes of aerophagia with threatening situations (mainly occurring in mentally disabled patients) [1]. Neuropsychiatric consulting and assessment is always recommended. In our two cases, after clinical evaluation, no organic disorders were identified and a behavioral approach was started, with improvement of symptoms. Speech therapy can be considered a very important approach as it may make the patient conscious of his/her behavior. A diet free of beverages containing gas may help reduce the volume of intra-intestinal gas and alleviate symptoms. In addition, drugs such as simethicone and dimethicone can reduce gas formation in the bowel [7]. The education of the parents in terms of gulping sounds and movements suggestive of air swallowing may be considered an important part of the combined therapy. Finally, a multidisciplinary approach, including good communication with the pediatrician and speech therapist, with strong support and education for the family, is advisable for the correct management of this functional disorder.

\section{References}

1 Bredenoord AJ: Management of belching, hiccups, and aerophagia. Clin Gastroenterol Hepatol 2013;11: 6-12.

-2 Loening-Baucke V: Aerophagia as cause of gaseous abdominal distention in a toddler. J Pediatr Gastroenterol Nutr 2000;31:204-207.

-3 Hwang JB, Choi WJ, Kim JS, Lee SY, Jung CH, Lee YH, Kam S: Clinical features of pathologic childhood aerophagia: early recognition and essential diagnostic criteria. J Pediatr Gastroenterol Nutr 2005;41: 612-616.

-4 Helgeland H, Flagstad G, Grøtta J, Vandvik PO, Kristensen H, Markestad T: Diagnosing pediatric functional abdominal pain in children (4-15 years old) according to the Rome III Criteria: results from a Norwegian prospective study. J Pediatr Gastroenterol Nutr 2009;49:309-315.

5 Maurage CCHM, Delaperriere NND, Orega MMO, Roulet Renolleau NNRR, Labarthe FFL, Faure NNF, Leddet IID, Robert MMR: Air swallowing in non-deficient children: an under-diagnosed disease. J Pediatr Gastroenterol Nutr 2004;39(suppl 1):S444.

6 Bredenoord AJ, Weusten BL, Timmer R, Smout AJ: Psychological factors affect the frequency of belching in patients with aerophagia. Am J Gastroenterol 2006;101:2777-2781.

7 Benninga MA, Peeters B, Hennekam RC: Fifth European Paediatric Motility Meeting. J Pediatr Gastroenterol Nutr 2011;53(suppl 2). 
Morabito et al.: Functional Aerophagia in Children: A Frequent, Atypical Disorder

Table 1. Identification of a patient with aerophagia based on the Rome III Criteria for FGIDs [4]

\section{Aerophagia}

Must include at least two of the following:

- Air swallowing

- Abdominal distension because of intraluminal air

- Repetitive belching and/or increased flatus

Table 2. Clinical evaluation of patients with aerophagia

\begin{tabular}{ll}
\hline Suggestive history & $\begin{array}{l}\text { bloating, belching, flatulence, distension, } \\
\text { constipation, abdominal pain, no } \\
\text { vomiting; history of trigger stressful } \\
\text { events }\end{array}$ \\
\hline Physical examination & $\begin{array}{l}\text { regular growth curve, increased tympany } \\
\text { over the abdomen, normal bowel sounds, } \\
\text { no signs of ileus or other alarm signs }\end{array}$ \\
\hline Laboratory investigations & $\begin{array}{l}\text { complete blood count, erythrocyte } \\
\text { sedimentation rate, C-reactive protein, } \\
\text { kidney and liver functionality tests, celiac } \\
\text { disease tests, paper radioimmunosorbent } \\
\text { test and radioallergosorbent test, iron } \\
\text { biochemical parameters, calprotectin, } \\
\text { urinalysis }\end{array}$ \\
\hline Abdominal radiograph & $\begin{array}{l}\text { distended bowels, large volume of } \\
\text { intestinal air, no air-fluid levels }\end{array}$ \\
\hline Investigations at the & $\begin{array}{l}\text { esophagogastroduodenoscopy, 24-hour } \\
\text { pH-metry, Hz breath test }\end{array}$ \\
\hline
\end{tabular}


Morabito et al.: Functional Aerophagia in Children: A Frequent, Atypical Disorder

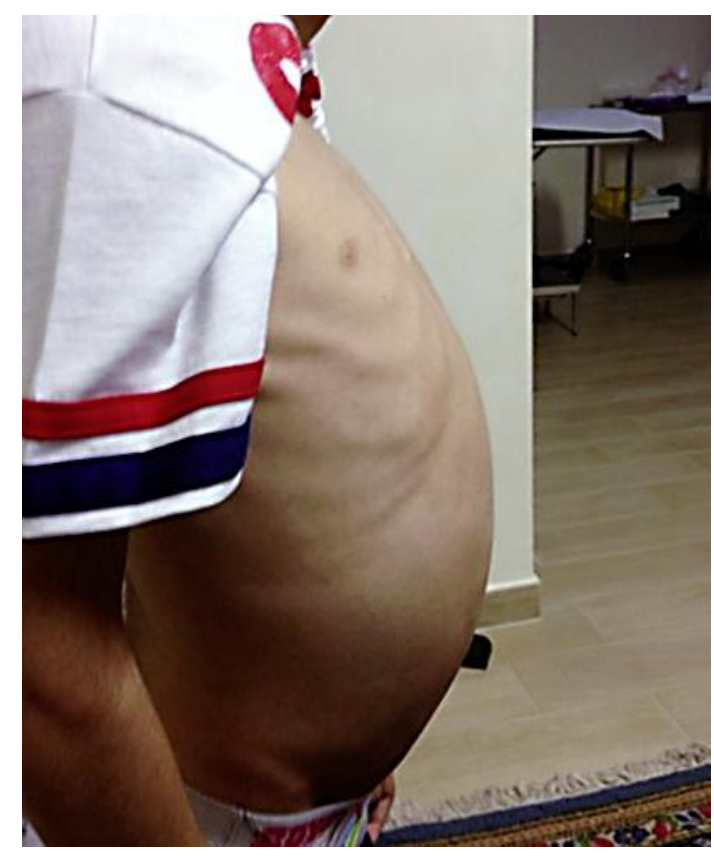

Fig. 1. FA in patient 1. Abdominal distension represents the most satisfactory criterion for diagnosis; it can be observed especially in the second part of the day.

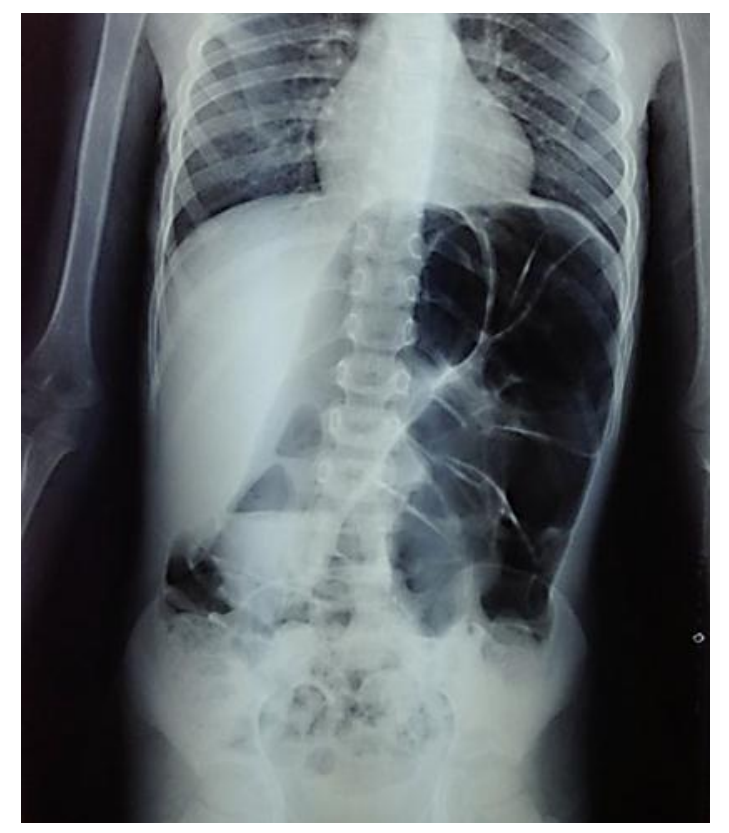

Fig. 2. FA in patient 1. Gaseous distension of the large bowel and rectum without signs of obstruction can be observed on orthostatic abdominal radiograph. 